\title{
Escherichia coli contamination of groundwater in Metro City, Lampung
}

\author{
Qanza Nurul Jannah ${ }^{1 *}$, and Gita Lestari Putri ${ }^{2}$ \\ ${ }^{1}$ Faculty of Engineering, Civil and Environmental Engineering Department, Universitas Indonesia, \\ Depok, 16424, Indonesia \\ ${ }^{2}$ Center for Sustainable Infrastructure Development, Universitas Indonesia, Depok, 16424, Indonesia
}

\begin{abstract}
Groundwater sources are widely used to supply water for drinking and other domestic purposes in Metro City, Indonesia. The presence of Escherichia coli (E. coli) is an indicator of fecal contamination in the water source. Therefore, this study was conducted to assess the level of $E$. coli contamination in groundwater at Metro City. The analysis was conducted on 253 households in 5 sub-districts using groundwater samples from different types of wells such as boreholes, protected wells, and unprotected wells. The E. coli concentrations were determined using the Colilert-18 method with IDEXX Quanti-Tray 2000 and the results showed the highest levels of contamination were in unprotected wells. E. coli was detected in $71 \%$ of water sources with $36 \%$ classified as very high risk or above 100 MPN (Most Probable Number)/100ml based on WHO standards. The findings, showed that the protection of water sources has the ability to reduce the risk of contamination.
\end{abstract}

\section{Introduction}

Groundwater is the main water source of domestic water, including drinking water, in developing countries [1] - [4] like Indonesia [5]. It is often a viable option due to its easy accessibility, low cost of development, and relatively good quality and quantity. [3], [6]. It is, however, susceptible to faecal contamination, which is often indicated by presence of Escherichia coli (E. coli) [7]. E. coli are considered acceptable indicators of fecal pollution by WHO [8].

$E$. coli is an indicator of faecal contamination in water sources, which often contains faecal pathogens that can harm human health through diseases such as diarrhea [9], [10]. Moreover, the consumption of groundwater contaminated by this microorganism increases the risk of diarrheal diseases as indicated by a study conducted in Juba, South Sudan [11].

Metro City in Lampung Province Indonesia is heavily dependent on groundwater for domestic needs. This is confirmed by the welfare Statistics of Lampung Province 2019, which showed that over $90 \%$ of the people in Metro City use dug wells and boreholes as the main water source for cooking, bathing, washing, and drinking [12]. Meanwhile, the safety of this water has never been confirmed and there is a concern for possible faecal

\footnotetext{
*Corresponding author: qanza.nurul@ui.ac.id
} 
contamination and associated health risks due to the high number of people using the water in the area. Therefore, it is important to further assess the E. coli concentration in Metro City's groundwater and this is the purpose of this research.

\section{Materials and Methods}

\subsection{Study Area}

This study was conducted in 5 sub-districts in Metro City, Lampung, Indonesia and these include Hadimulyo Barat Sub-district in Central Metro District, Karangrejo Sub-district in North Metro District, Ganjarasri Sub-district in West Metro District, Iringmulyo Subdistrict in East Metro District, and Rejomulyo Sub-district in South Metro District as indicated in Fig. 1. Hadimulyo Barat has a population of 14,012 people with a population density of 9,341 people $/ \mathrm{km}^{2}$, Karangrejo has a population of 8,494 inhabitants with a population density of 1,100 people $/ \mathrm{km}^{2}$, Ganjarasri has a population of 9,426 persons with a population density of 3,895 people $/ \mathrm{km}^{2}$, Iringmulyo has a population of 15,387 people with a population density of 8,141 people $/ \mathrm{km}^{2}$, and Rejomulyo has a population of 4,729 people with a population density of 995 people $/ \mathrm{km}^{2}$. These locations were selected due to their dense population, high poverty rates (Hadimulyo Barat: 858 households, Karangrejo: 740 households, Ganjarasri: 417 households, Iringmulyo: 522 households, and Rejomulyo: 326 households), high groundwater use (Central Metro: 87\%, North Metro: 95\%, West Metro: 78\%, East Metro: 74\%, South Metro: 92\%), and limited piped water services (Metro City: $20.29 \%$ ).
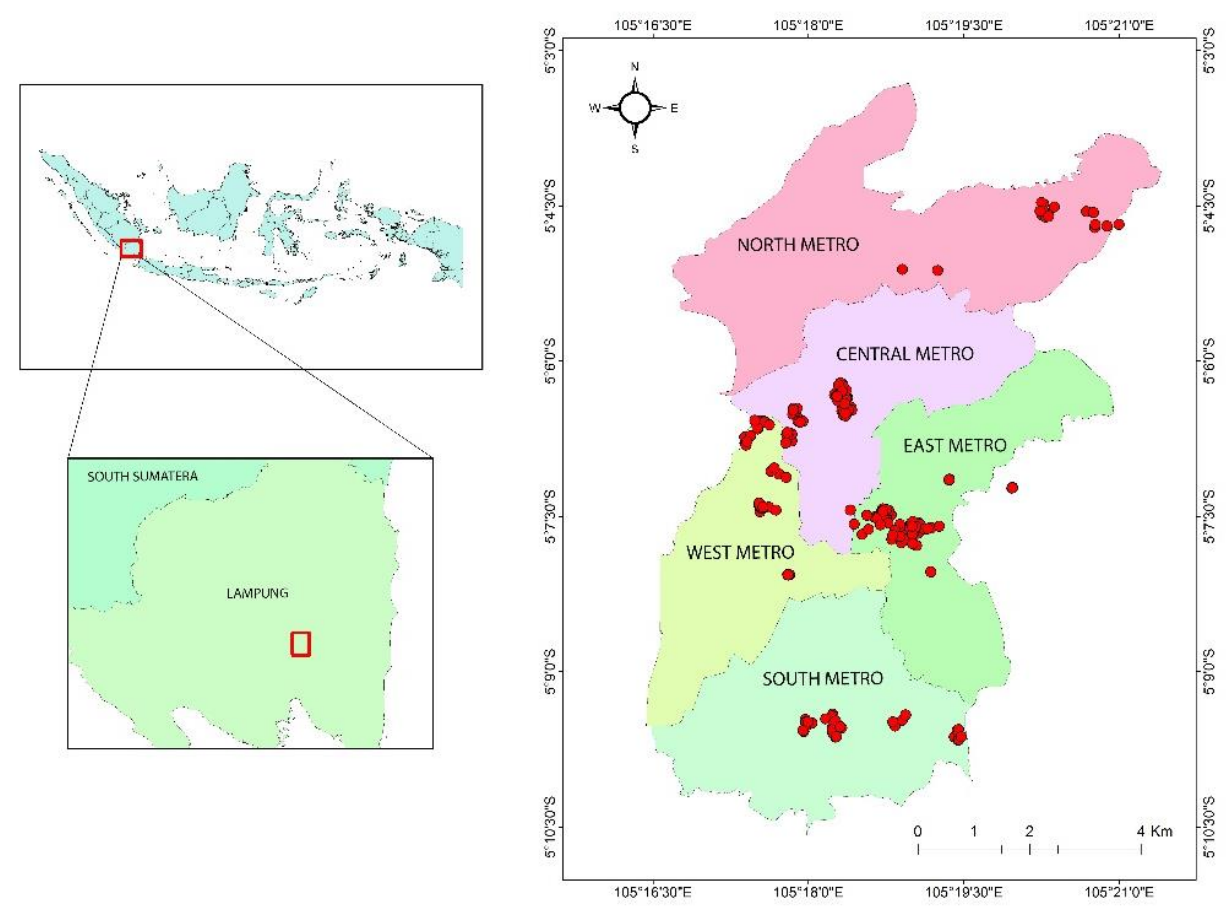

Fig. 1. The area of study along with sampling location. 


\subsection{Water sampling and sample analysis}

The sampling was conducted in dry seasons from October to November 2020 with an average precipitation of $3.89 \mathrm{~mm}$ per day. A total of 253 water samples were taken, including 75 from Hadimulyo Barat, 40 from Karangrejo, 34 from Ganjarasri, 69 from Iringmulyo, and 35 from Rejomulyo (Table 1). Based on the types of the wells, the samples were obtained from 3 sources which include 61 from boreholes, 14 from protected wells, and 178 from unprotected wells. The samples were, however, selected randomly with the number proportional to the population of each sub-district.

Table 1. The number of samples.

\begin{tabular}{|c|c|c|c|c|}
\hline \multirow{2}{*}{ Location } & \multicolumn{4}{|c|}{ Water Sources } \\
\hline & Borehole & Protected well & Unprotected well & Total \\
\hline Hadimulyo Barat (Central Metro) & 43 & 2 & 30 & 75 \\
\hline Karangrejo (North Metro) & 2 & 3 & 35 & 40 \\
\hline Ganjarasri (West Metro) & 9 & 1 & 24 & 34 \\
\hline Iringmulyo (East Metro) & 5 & 7 & 57 & 69 \\
\hline Rejomulyo (South Metro) & 2 & 1 & 32 & 35 \\
\hline Total & 61 & 14 & 178 & 253 \\
\hline
\end{tabular}

The water sampling process was initiated by taking water from the kitchen tap which was prioritized because it is the source of the water usually used for consumption purposes. The bathroom faucet, indoor faucet, outdoor faucet, hand pump, or well bucket was used in places without kitchen tap. A total of $100 \mathrm{ml}$ of the sample were taken and put into WhirlPak bags and immediately cooled to a temperature of $\leq 4^{\circ}$ using an ice pack and placed in a cooler bag. They were transferred to the laboratory and analyzed on the same day within 6 h.

The E. coli concentration was analyzed using the Colilert-18 Quanti-Tray/2000 system from IDEXX. This involved mixing the $100 \mathrm{~mL}$ water sample with Colilert-18 reagent after which the mixture was moved to the Quanti-tray/2000 and sealed in the sealer. The sealed samples were later incubated for 18 to 22 hours at $35 \pm 0.5^{\circ} \mathrm{C}$ temperature, and the tray was placed under UV light for fluorescence to determine the result. The number of fluorescent wells was, however, quantified to determine the E. coli concentration in Most Probable Number (MPN) according to the IDEXX Quanti-Tray®/2000 MPN Table. Moreover, quality control was also included in this study by creating field blank, laboratory blanks, and duplicates, once per sampling day, to prevent contamination in the sampling and analysis procedure.

\section{Results}

E. coli was detected in 181 out of 253 water samples at different concentrations. Unprotected wells were observed to be more contaminated than boreholes and protected wells as presented in Fig. 2. The average concentration of E. coli in unprotected wells is $1.59 \log \mathrm{MPN} / 100 \mathrm{ml}$, while protected wells is $1.06 \log \mathrm{MPN} / 100 \mathrm{ml}$, and borehole is 0.49 $\log \mathrm{MPN} / 100 \mathrm{ml}$. Overall, the average E. coli concentration in Metro City was 1.31 $\log \mathrm{MPN} / 100 \mathrm{ml}$. 


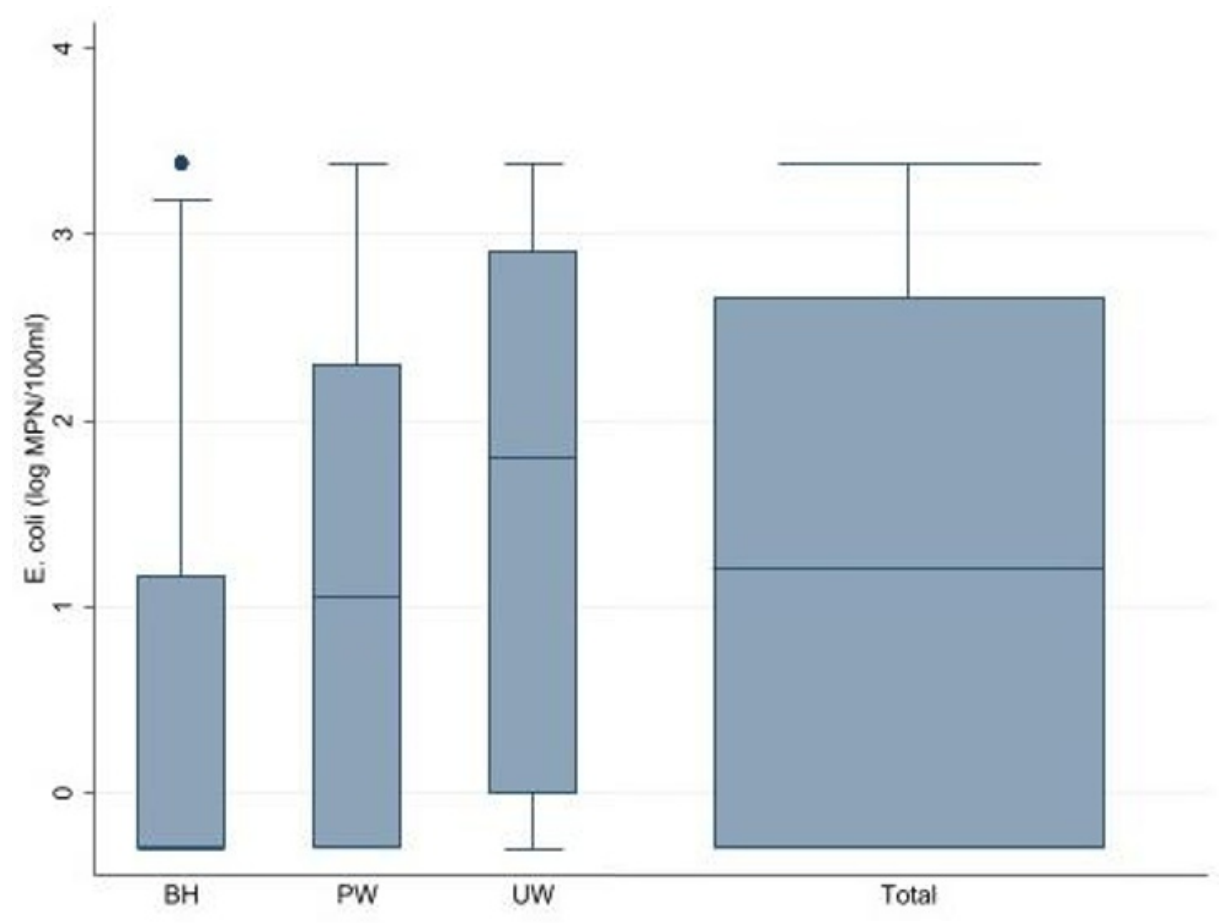

Fig. 2. E. coli contamination based on the types of wells in Metro City.

(BH: borehole, PW: Protected well, UW: unprotected well)

The E. coli concentrations were categorized based on the World Health Organization (WHO) guidelines to identify the percent risk of contamination in Metro City. The categories include (i) <1MPN/100ml, (ii) 1-10 MPN/100ml, (iii) 10-100 MPN/100ml, and (iv) $>100 \mathrm{MPN} / 100 \mathrm{ml}$. A total of $28 \%$ were classified as low risk, $17 \%$ as moderate risk, $18 \%$ as high risk, and $36 \%$ showed very high risk as indicated in Figure 3 . Based on the types of well, borehole had the lowest risk of contamination with E. coli not being detected in $54 \%$ of samples, while unprotected well had the highest risk with $46 \%$ of samples having $>100 \mathrm{MPN} / 100 \mathrm{ml}$. 


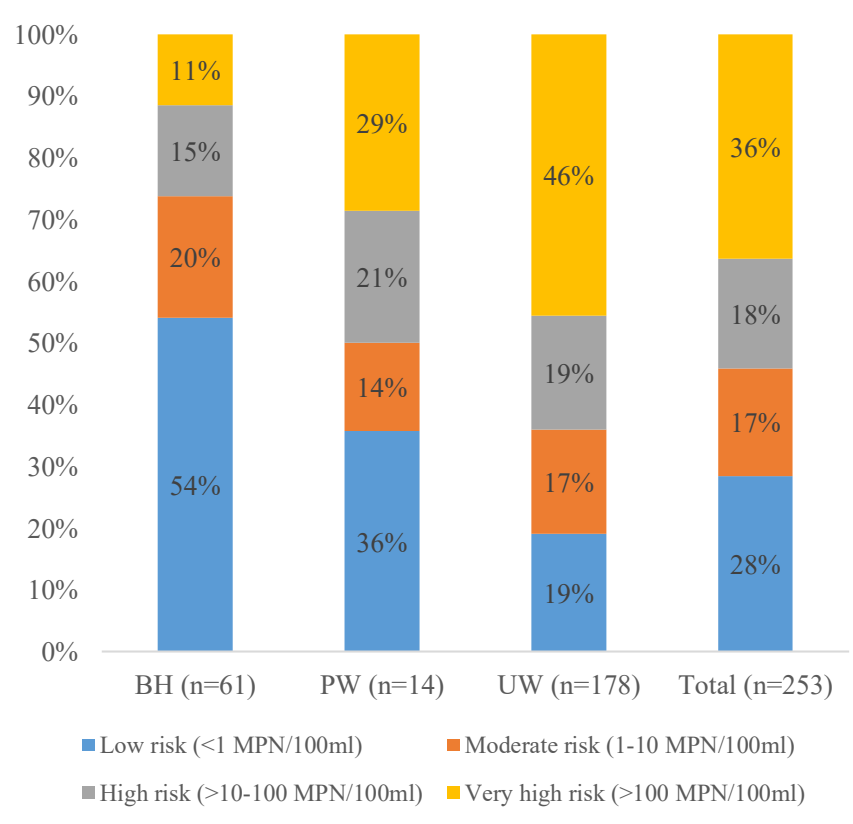

Fig. 3. The percent risk of E. coli contamination in Metro City.

(BH: borehole, PW: Protected well, UW: unprotected well)

\section{Discussion}

Overall, the level of E. coli contamination in Metro City is relatively high. This is evident in the fact that $E$. coli was present in $72 \%$ of water sources, with $36 \%$ discovered to be having $E$. coli concentrations classified as very high risk. According to the World Health Organization (WHO), E. coli is expected to be undetectable in $100 \mathrm{ml}$ of drinking water sample and this means $72 \%$ of the water sources in the city need to be treated by boiling [13] before consumption. This is important because the consumption of water with faecal contamination has the ability to cause diarrhea [9].

Boreholes had the lowest E. coli contamination while unprotected wells were more polluted. The latter is possibly associated with the inability of the infrastructure in unprotected wells to protect the groundwater from contamination compared to the other types of wells. A previous study also showed protected well and unprotected well are more susceptible to contamination than boreholes [14]-[16]. According to observations, this might be due to the greater depth of boreholes when compared with the other wells. The microbial contaminants originating from the surface, such as runoff of fecal material, getting lost at a depth of $30 \mathrm{~m}$ due to filtration by rocks [1]. In additional, protected well and unprotected well usually used rope and bucket to withdraw water. Using rope and bucket can contaminate water as the rope and bucket can be contaminated with dust and animal waste [16], [17].

Unprotected wells usually do not have well lining, wellhead, well platform, and are not covered and this makes it easy for animal droppings to enter [18] and this shows the possibility of having the pollutants entering the wells through several means. For example, contaminated water can flow underground in a well without lining through the sides [16]. It is also important to note that the lack of a well platform or presence of cracks on the platform has the ability to cause the direct entrance of contaminants through the unsaturated zone, thereby, polluting the groundwater [19]. Meanwhile, a well cover can protect the well 
water from bacteria carried by the wind, withstand the water spills possibly contaminated by bacteria, as well as protect the well from runoff during rain [20]. An investment for good well infrastructure would be less susceptible to contaminants.

\section{Conclusion}

Overall, the level of E. coli contamination in Metro City is relatively high. This is evident in the fact that $72 \%$ of water sources are polluted, where $36 \%$ having a very high risk. While only $28 \%$ are not polluted. Moreover, unprotected wells were found to be more susceptible to contamination than boreholes and protected well and this is associated with the poor infrastructure of unprotected wells which leads to a higher rate of $E$. coli contamination. Therefore, it is urgent that unprotected well owners worldwide, including residents of Metro City, need to improve their well infrastructure for a cleaner water supply.

This research was funded by the Water for Women from the Australian Government Department of Foreign Affairs and Trade (number WRA1: 1004) and the conference funding is supported by PTUPT 2021 with contract number NKB-278/UN2.RST/HKP.05.00/2021 from Ministry of Research and Technology / National Research and Innovation Agency of Indonesia and also PPKI program from the Indonesia World Class University Research Scheme. Thanks to Cindy Rianti Priadi from Universitas Indonesia, Tim Foster, Prof. Juliet Willets and Franziska Genter from University of Technology Sydney and also Angela Harris from North Carolina State University for advising on this research.

\section{References}

1. N. A. G. Moyo, Phys. Chem. Earth 66, 27-32 (2013).

2. D. J. Lapworth, D. C. W. Nkhuwa, J. Okotto-Okotto, S. Pedley, M. E. Stuart, M. N. Tijani, J. Wright, Hydrogeol. J. 25, 1093-1116 (2017).

3. A. M. MacDonald, H. C. Bonsor, B. É. Ó. Dochartaigh, R. G. Taylor, Environ. Res. Lett. 7, (2012).

4. N. Carrard, T. Foster, J. Willetts, Water (Switzerland) 12, (2019).

5. M. P. Dayanti, M. F. Fachrul, A. Wijayanti, Escherichia coli as bioindicator of the groundwater quality in Palmerah District, West Jakarta, Indonesia. IOP Conf. Ser. Earth Environ. Sci. 106, (2018).

6. K. Grigoryan, G. Badalyan, M. Sargsyan, A. Harutyunyan, LWT - Food Sci. Technol. 58, 360-363 (2014).

7. V. Masindi, S. Foteinis, Clean. Eng. Technol. 2, 100038 (2021).

8. S. Maysarah, G. L. Putri, M. A. Pratama, F. Zulkarnain, J. Willetts, T. Foster, F. Genter, A. Harris, C. R. Priadi. IOP Conf. Ser. Earth Environ. Sci. 566, 012008 (2020).

9. B. Abera, B. Bezabih, D. Hailu, Sustain. Water Qual. Ecol. 9-10, 22-26 (2017).

10. Y. Rohmah, A. Rinanti, D. I. Hendrawan, The determination of ground water quality based on the presence of Escherichia coli on populated area (a case study: Pasar Minggu, South Jakarta). IOP Conf. Ser. Earth Environ. Sci. 106, (2018).

11. E. Engström, B. Balfors, U. Mörtberg, R. Thunvik, T. Gaily, M. Mangold, Sci. Total Environ. 515-516, 181-187 (2015).

12. Statistics of Lampung Province, Welfare Statistics of Lampung Province 2019 (2019).

13. S. V. Sodha, M. Menon, K. Trivedi, A. Ati, M. E. Figueroa, R. Ainslie, K. 
Wannemuehler, R. Quick, J. Water Health 9, 577-585 (2011).

14. G. Lutterodt, J. van de Vossenberg, Y. Hoiting, A. K. Kamara, S. Oduro-Kwarteng, and J. W. A. Foppen, Int. J. Environ. Res. Public Health 15, 1-12 (2018).

15. T. Foster, J. Willetts, and K. K. Kotra, J. Water Health 17, 737-748 (2019).

16. E. Elisante and A. N. N. Muzuka, Environ. Monit. Assess. 188, (2016).

17. J. F. T. K. Akoachere, L. A. Omam, T. N. Massalla. BMC Public Health 13, (2013).

18. WHO/UNICEF. Core questions on drinking-water. World Heal. Organ. 25 (2006).

19. N. Ferrer, A. Folch, G. Masó, S. Sanchez, X. Sanchez-Vila, J. Contam. Hydrol. 228, 103556 (2020).

20. C. K. Kiptum and J. M. Nbambuki, Int. J. Water Resour. Environmen 4, 35-43 (2012). 